NIHON REOROJĪ GAKKAISHI Vol. 25, No. 3, 119 123 (1997)

C)1997 The Society of Rheology, Japan

論文

\title{
Rheological Properties of Synthetic Saponite/Water Dispersions
}

\author{
Tsunemi MonMA*1, Masuo KudO*2 and Toru MASUKO*2 \\ ${ }^{* 1}$ Kunimine Industries CO., LTD 1-10-5, Iwamoto, Chiyoda, Tokyo, 101, Japan \\ ${ }^{* 2}$ Faculty of Engineering, Yamagata University 4-3-16, Jonan, Yonezawa, Yamagata, 992, Japan
}

\begin{abstract}
Static and dynamic viscoelastic properties of synthetic saponite (Sumecton SA) / water dispersion systems have been investigated at $20^{\circ} \mathrm{C}$. Solid concentrations of the system were changed in the range from 1 to $3 \mathrm{wt} \%$. At low concentrations less than $1.1 \mathrm{wt} \%$ of solid content, the dispersions showed a typical Newtonian flow, however they exhibited a distinct shear thinning effect at concentrations exceeding $1.2 \mathrm{wt} \%$. This indicates that the coagulated structure of the saponite particles in the system begins to form at a concentration of $1.2 \mathrm{wt} \%$. Alternatively, at concentrations higher than $1.5 \mathrm{wt} \%$, the dispersions showed high storage moduli in the order of $10 \mathrm{~Pa}$, due to formation of a gel structure. This structure was broken down by an applied weak strain, and later revealed rapid structural recovery. The scaling index calculated from the log-log plot of storage modulus against solid concentration was 5.3, larger than that of the commercial Namontmorillonite or the synthetic hectorite suspensions.
\end{abstract}

Key Words: Synthetic saponite/Rheological properties/Water dispersion/Non-Newtonian flow

\section{合成サポナイト／水分散系のレオロジー特性}

\author{
門馬 恒視 ${ }^{* 1}$ 工藤 益男 ${ }^{* 2}$ 増子 徹 ${ }^{* 2}$
}

（原稿受理：1996年10月28日）

\section{1. 緒言}

スメクタイトは，板状結晶が層状に積層した無機化合物である が，これを水等の溶媒と混合させると層間に水が侵入するため極 微細な板状結晶に䢃開される。この分散粒子は，交換性のカチオ ンを持つ層表面が負に帯電しており，これが正電荷を持つ粒子端 部之結合することによりカード八ウス構造を形成しそのためゲル 化すると考えられている(1) (3)。このようなスメクタイトの特性 は, 泥水, 化粧品, 塗料, 農薬, 医薬品などのレオロジー改質材 として多方面に利用されている( .

一般に用いられるスメクタイトは，ほとんぞが天然の粘土岩か ら得られ, 一部のみが工業薬品から合成されている. 後者の合成 スメクタイトは, 天然品と比較して結晶粒子サイズが小さいこと からコロイド化された分散液は透明かつゲル強度の点で優れてお り ${ }^{5)} り$ ，また夾雑物を含まないことから特に化粧品や塗料の分野 への応用が期待されている.

現在市販されている合成スメクタイトとして，サポナイト，へ クトライト，スチーブンサイトが挙げられる。何れも3-八面体
型スメクタイト構造をむつコロイド性含水珪酸塩であるが，化学 組成が一部異なっている゙ . 合成サポナイトは, 四面体の $\mathrm{Si}^{4+}$ の一部が $\mathrm{Al}^{3+}$ に同形置換をし結晶格子内に負電荷を持つ。一方, 合成へクトライトは, 八面体の $\mathrm{Mg}^{2+}$ の一部が $\mathrm{Li}^{+}$に同形置換 をし結晶格子内に負電荷を持っている. また, 合成スチーブンサ イトは, 八面体の $\mathrm{Mg}^{2+}$ の一部が欠落しているため結晶格子内 に負電荷を持っている. これらの同形置換による結晶格子内の負 電荷は, 結晶格子層面上あるいは層間に存在するが, その強度は, 同形置換をしている部位と量に影響を受ける7). したがって，合 成スメクタイト／水分散系の流動特性は, その化学組成に強く支 配されると予想される.

従来より, 合成へクトライトの流動特性については部分的な研 究がなされてきたが8)，他の合成スメクタイトの流動特性につい てはほとんど報告されていない，そこで本研究では，粒子濃度を 変化させた合成サポナイト／水分散系について，静的および動的 粘弾性測定を行うことによりその流動特性を検討した。

\section{2. 試料および実験方法}

$2 \cdot 1$ 試料

合成サポナイトとして, クニミネ工業(㑣)製スメクトン SA を用 
いた，その化学組成を Table I に示す．スメクトンSA は, 四 面体の $\mathrm{Si}^{4+}$ の一部が $\mathrm{Al}^{3+}$ に同形置換をすると共に，八面体の $\mathrm{Mg}^{2+}$ の一部が $\mathrm{Al}^{3+}$ に同形置換をしている ${ }^{9)}$.

水分散液中における分散粒子の粒度分布をマイクロトラック $\mathrm{UPA}$ (日機装(㑣)製)により測定した結果，体積平均粒子径 $\left(D_{50}\right)$ は $92 \mathrm{~nm}$ であった。この時, 分散液の $\mathrm{pH}$ は 10 である.

Table I Chemical composition(wt\%) of Sumecton SA.

\begin{tabular}{lr}
\hline $\mathrm{SiO}_{2}$ & 54.71 \\
$\mathrm{Al}_{2} \mathrm{O}_{3}$ & 5.02 \\
$\mathrm{Fe}_{2} \mathrm{O}_{3}$ & 0.03 \\
$\mathrm{MgO}$ & 30.74 \\
$\mathrm{Na}_{2} \mathrm{O}$ & 2.15 \\
$\mathrm{SO}_{3}$ & 0.67 \\
$\mathrm{H}_{2} \mathrm{O}$ & 6.67 \\
\hline
\end{tabular}

\section{$2 \cdot 2$ 分散試料の調製}

$20^{\circ} \mathrm{C}$ において蒸留水 $200 \mathrm{ml}$ をプロペラ擋抖機で擋拌 $(800 \mathrm{rpm})$ しながら，所定の濃度になるように SA を投入した，その後，擋 找を 10 分間継続してから， $20^{\circ} \mathrm{C}$ の恒温器内に 3 日以上静置し分 散液を熟成安定させた。

\section{$2 \cdot 3$ 流動特性の測定}

$2 \cdot 3 \cdot 1$ 静的粘弾性測定

コーンプレート型回転粘度計(東京計器侏)製， E 型粘度計 EHD 型または ELD 型)を用いて，粒子濃度 $1.0 \sim 3.0 \mathrm{wt} \%$ の分散液に ついて静的粘弾性測定を行った。測定温度を $20^{\circ} \mathrm{C}$ と，コーン

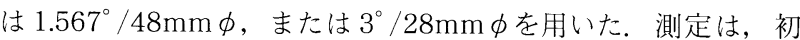
めに印加可能な最高せん断速度で 5 分間擋拌して構造を破壊し た後，5 分間静置して開始した。

1.92 383 $\mathrm{s}^{-1}$ の間の 8 水準のせん断速度を設定し，低せん 断速度から高せん断速度へ段階的に変えながら 2 分毎にせん断 応力を測定した (UP 過程).さらに最高せん断速度に達した後, 順次せん断速度を下降させてせん断応力の測定を行った(DOWN 過程).

\section{$2 \cdot 3 \cdot 2$ 動的粘弾性測定}

動的粘弾性測定は，コーンプレート型回転粘度計(㑣)レオロジ 製,ソリキッドメーターMR-300)を用いた。使用したコーンサ

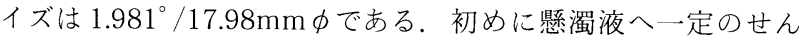
断力を加え構造を破壊した後, 5 分間静置後測定を開始した。測 定温度は $20^{\circ} \mathrm{C}$ である。なお，歪依存性の評価では，角速度 $(\omega)$ を6.283rad / $\mathrm{s}$ に固定し，歪み $(\gamma)$ を $1.51 \sim 253.86 \%$ の範囲で 変化させ, 貯蔵弾性率 $\left(G^{\prime}\right)$ および損失弾性率 $\left(G^{\prime \prime}\right)$ を測定した。 また， $G^{\prime}$ の角速度依存性を観察するため， $\gamma=10 \%$ とし，角速 度 $\omega$ を $0.0126 \sim 12.82 \mathrm{rad} / \mathrm{s}$ に变化させ，分散粒子濃度 $1.0 \sim 3.0$ wt\%について $G^{\prime}$ を測定した。

\section{$2 \cdot 3 \cdot 3$ ゲル強度回復速度測定}

上記ソリキッドメーターMR-300 を用い，ゲル強度回復測定を 行った。使用したコーンサイズ，測定温度は前項之同じである。 最初に一定のせん断力を加え構造を破壊した後, 直ちに $\omega=$ $0.628 \mathrm{rad} / \mathrm{s}, \quad \gamma=0.8 \%$ における $G^{\prime}$ を測定し，ゲル強度回復の 時間依存性を観察した。

\section{3. 結果および考察}

\section{$3 \cdot 1$ 静的粘弾性特性}

スメクトン SA の分散粒子濃度を $1.0 \sim 3.0 \mathrm{wt} \%$ として定常流 測定を行った結果を Fig. 1 に示した. 1.2wt\%未満の濃度では, 䀣濁液はニュートニアン的な流動挙動を示したが， $1.2 \mathrm{wt} \%$ 以上 では，ヒステリシスループを伴う shear thinning 効果が現れた。 スメクトン SA の真密度を $2.5 \mathrm{~g} / \mathrm{cm}^{3}$ とて， $1.2 \mathrm{wt} \%$ 分散液中 の粒子体積分率を計算すると $0.48 \mathrm{vol} \%$ となり，非常に低い粒子 体積分率において分散液の構造が大きく変化していると考えられ る.

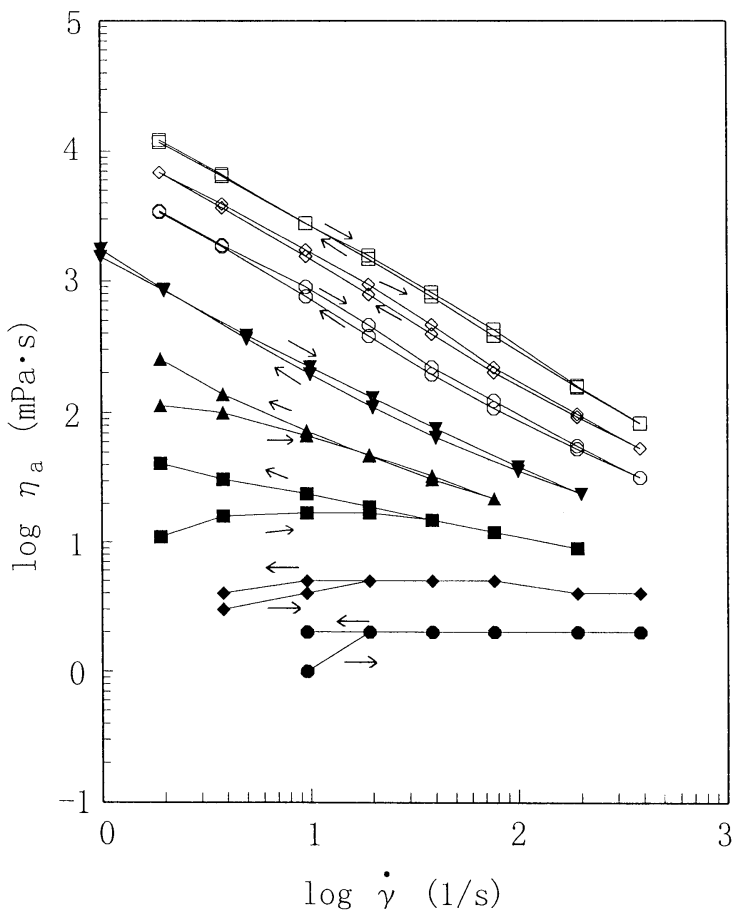

Fig. 1 Changes in apparent viscosity of synthetic saponite/water dispersions at various concentrations Solid concentration (wt\%): $\mathbf{0}, 1.0 ; \bullet, 1.1 ; \boldsymbol{\square}, 1.2 ; \boldsymbol{\Delta}$ $1.3 ; \boldsymbol{\nabla}, 1.5 ; \bigcirc, 2.0 ; \diamond, 2.5 ; \square, 3.0$.

また Fig. 1 からは， みかけ粘度のせん断速度依存性における ヒステリシス性が，分散液の濃度変化に従い変化していることが 観察される。すなわちスメクトン SA の希薄分散液 (1.1 wt\%以 下)では，僅かにヒステリシスループを示すが，分散液の構造が 大きく変化する $1.2 \mathrm{wt} \%$ 近傍では, DOWN 過程において，粘度 上昇が認められチキソトロピーが逆転する現象 (negative shear thixotropy)を認めた. $1.2 \mathrm{wt} \%$ では，UP過程において，せん断 速度 $1.92 \mathrm{~s}^{-1}$ の時，みかけ粘度は $11 \mathrm{mPas}$ を示したが，DOWN 過程ではそれより大きく $41 \mathrm{mPas} と な っ た 。 し か し ， 2.0 \mathrm{wt} \%$ 以 上の場合では通常のチキソトロピー現象を示し, 濃度の上昇に伴 いヒステリシス性む小さくなっている.

中石ら ${ }^{10)}$ １1) は， ベントナイト分散液のせん断応力とせん断速 度の関係において, Maxwell モデルを用いせん断応力測定にお けるタイムスケールとゲルの緩和時間に基づく解析を行っている. その中で，測定時間を一定とした際，ゲルの緩和時間を長くする 
要因(分散液濃度を上げる)を与えるか，むしくは，緩和時間が一 定のゲルにおいて測定時間を短くした際， negative shear thixotropy が発現することを示唆している. しかし, 本研究の 場合, 中石らが negative shear thixotropy 現象を観察した場合 よりも測定時間が十分長いにもかかわらず, negative shear thixotropy 現象が観察された点で中石らの研究とは異なってい る.

その理由として, スメクトン SA の低濃度ではゲル構造の回復 速度が遅く, 5 分間の静置時間で十分にゲル構造が回復していな いため, UP 過程において見掛け粘度が低くなり，DOWN 過程 では，測定中にゲル構造が回復したために見掛け粘度が高くなっ た事によるあのと考えられる。 また，ベントナイトとスメクトン SA との凝集状態の差による回復速度の差も影響していると考え られる.

\section{$3 \cdot 2$ 動的粘弾性特性}

前項と同じく分散粒子濃度を $1.5 \sim 3.5 \mathrm{wt} \%$ に变化させた分散

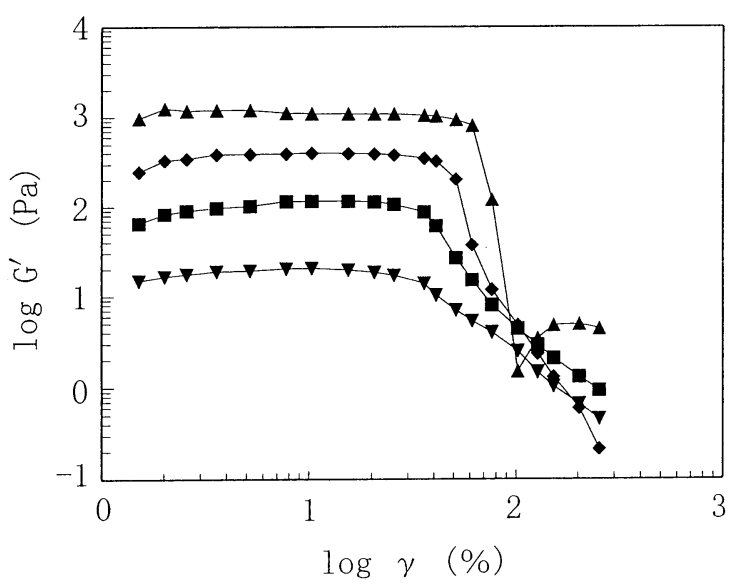

Fig. 2 Strain amplitude dependence of $G^{\prime}$ for synthetic saponite/water dispersions at various concentrations. Solid concentration $($ wt $\%): \boldsymbol{\nabla}, 1.5 ; \boldsymbol{\square}, 2.0$; $2.5 ; \boldsymbol{\Delta}, 3.0$.

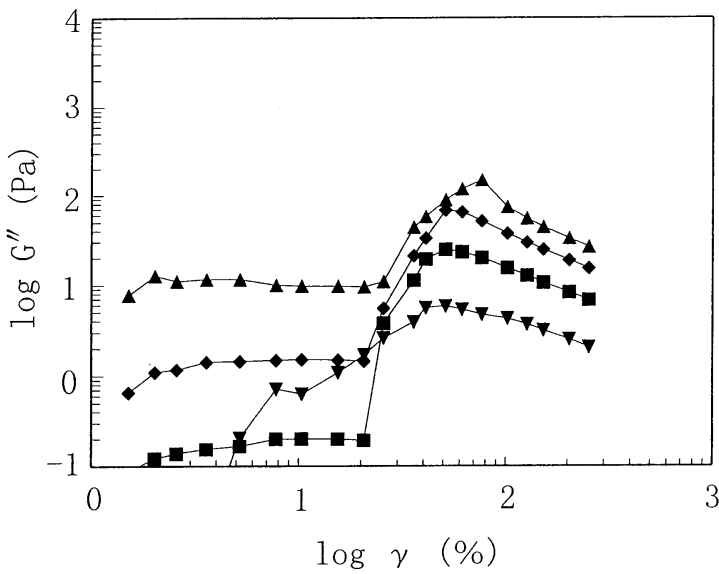

Fig. 3 Strain amplitude dependence of $G^{\prime \prime}$ for synthetic saponite/water dispersions at various concentrations. Solid concentration (wt \%): $\boldsymbol{\nabla}, 1.5 ; \mathbf{\square}, 2.0$; $2.5 ; \boldsymbol{\Lambda}, 3.0$

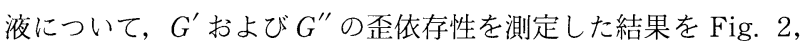
Fig. 3 に示した. 1.5wt\%では $G^{\prime}$ の值が緩やかに低下すると共 に $G^{\prime \prime}$ の值が上昇して，ゲル構造の緩やかな崩壊が起こっている のに対し， $2.0 \mathrm{wt} \%$ では $\gamma \fallingdotseq 40 \%$ で急激に $G^{\prime}$ の值が低下すると 共に $G^{\prime \prime}$ の值が $\gamma=50 \%$ の近傍に急峻なピークを示すことから， ゲルからゾルへの急激な転移が起こっていることを示唆している. また， $G^{\prime}$ の值が上昇すると共にゲル構造の崩壊を起こす $\gamma$ の值 あ増大し，ゲル構造が強固になることを示している.

Ramsay ${ }^{12)}$ は, ベーマイト/水系のゲル構造について動的粘 弾性のデー夕から，粒子が凝集して 3 次元的に広がった網目構 造，すなわちゲルを形成する場合の粒子凝集エネルギーを算出し た。 いま, $G^{\prime}$ の值が急激に減少する際の歪みを $\gamma_{c}$, その際の応 力を $\sigma_{c}$ とすると, 式(1)から粒子凝集エネルギー $\left(E_{c}\right)$ が得られる.

$$
E_{c}=\int_{0}^{\gamma_{c}} \sigma d \gamma
$$

式(2)の Hook の法則を用いて書き替えると式(3)が導き出され $3^{13)}$.

$$
\begin{aligned}
& \sigma=G^{\prime} \gamma \\
& E_{c}=\frac{1}{2} G^{\prime} \gamma_{c}{ }^{2}
\end{aligned}
$$

一般に $G^{\prime}$ は，隣接する粒子間の距離と結合力の関数として表 される ${ }^{14)}$. 粒子間の距離が分散液濃度 $C$ によって決定されると 仮定すると， $K$ を濃度に依存しない定数として式(4)のように表 わすことが可能であろう。

$$
G^{\prime}=K C^{q}
$$

Fig. 4 は, 歪依存性の結果より得たゲル構造が崩壊する前の $G^{\prime}$ の值を, 分散粒子濃度 $(C)$ について対数プロットした図である. 得られた直線関係から，式(5)が求められた。

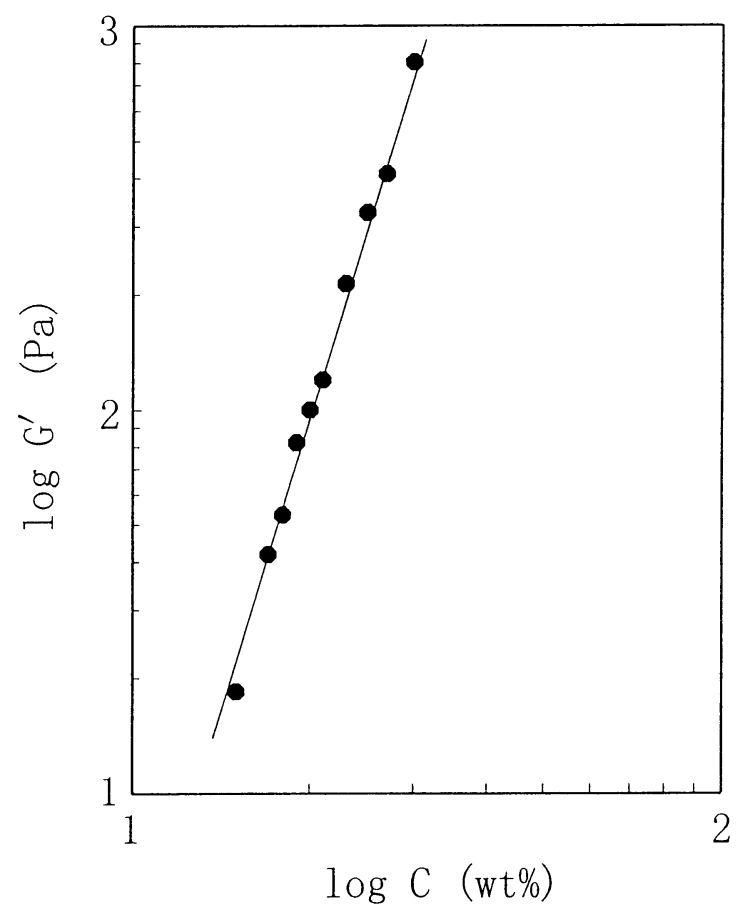

Fig. 4 Concentration dependence of $G^{\prime}$ for synthetic saponite/water dispersions. 


$$
G^{\prime} \propto C^{5.3}
$$

また，同様に $E_{c}$ と $\sigma_{c}$ についても濃度指数を求めた. その結果を 式(6), 式(7)に示す.

$$
\begin{aligned}
& E_{c} \propto C^{8.5} \\
& \sigma_{c} \propto C^{6.9}
\end{aligned}
$$

Miano ${ }^{15)}$ は, $\mathrm{Na}$ 型ベントナイトの希薄分散安定液に塩類を 添加し, 凝集する前の分散安定液と凝集後の $G^{\prime}$ につて, 式(4) における指数 $q$ の変化を比較し, 分散液が安定な場合 $q=8 \sim 11$ となり, 凝集した際 $q=2 \sim 3$ に減少することを報告している. また, 塩濃度をさらに増加させ分散粒子を強く凝集させても $q$ 值 に変化が現れず， $G^{\prime}$ の值の増加が観察されたことを報告してお り, $q$ の検討によりスメクタイトの分散状態を推測できることを 示唆している.

一方, Sohmら ${ }^{13)}$ 及びCallaghanら ${ }^{16)}$ は，市販されている Na 型ベントナイトを用い，指数 $q=3.7$ 及び 3.2 を得ている。彼ら はベントナイト分散粒子が，高い $\mathrm{pH}$ において分散状態にあるこ と，またゲル構造が，ベントナイト中に含まれる塩類により電気 二重層が圧縮され，その結果発現した面-端むしくは端-端結合に よるあのであることを指摘している.

また，合成へクトライト(Laponite RD)については，Ramsay $ら^{17)}$ が $q=2.78$ を見出した。 Ramsay らは合成へクトライトの ゲル構造について，合成へクトライト／水分散液に拈ける前述の 粒子凝集エネルギーの結果より, 粘上分散粒子の面之面との間に おける斥力よりゲル化すると考察している. しかし, 彼らのスケ一 リングによる解析は，むしろ凝集状態形成を示しており， Na 型 ベントナイトと同様に夾雑塩類による面-端もしくは端-端結合に よるゲル構造が形成されていると推測される.

スメクトン SA の場合，スケーリングによる解析は， $G^{\prime}$ の指 数 $q$ は式(5)より 5.3 であり, $\mathrm{Na}$ 型ベントナイトや合成へクトラ イトよりも指数が大きいことから，スメクトン SA の粒子が，静 電ポテンシャルに基づく斥力と, van der Waalsによる引力之 の間で均衡を保つことにより分散安定し, Na 型ベントナイトや 合成へクトライトよりも粒子が緩やかな凝集状態を形成すること によりゲル化していることが推測される，スメクトン SA が形成

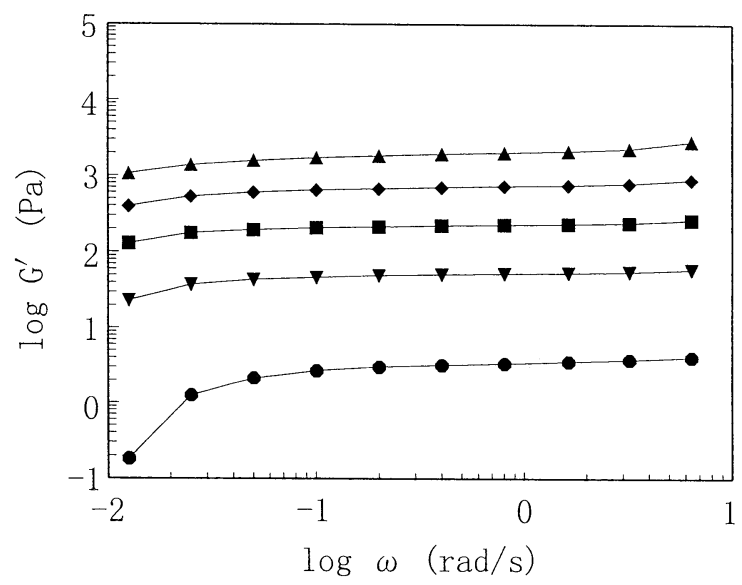

Fig. 5 Frequency dependence of $G^{\prime}$ for synthetic saponite/water dispersions at various concentrations. Solid concentration (wt\%):, $1.0 ; \boldsymbol{\nabla}, 1.5 ; \mathbf{\square}, 2.0$; $2.5 ; \boldsymbol{\Delta}, 3.0$.
するゲルが，少ない歪みで急激に崩壊する特性は，この粒子の凝 集状態に由来することが推測される。

次に，スメクトン SA の分散粒子濃度を $1.0 \sim 3.0 \mathrm{wt} \%$ に变化 させた場合の $G^{\prime}$ の角速度依存性を測定した結果を Fig. 5 に示す. 分散粒子濃度の上昇に伴い，ゲル構造に基づく第二平坦部を示す 角速度の範囲が広くなり，その範囲に扔いてスメクトン SA が形 成するゲル構造が保たれていることが推察される．また， $1.0 \mathrm{wt}$ \%においても第二平坦部を示していることから，スメクトン SA の希薄分散液において，低い歪みにおいては弱いながらもゲル構 造を形成していることが推測される.

\section{$3 \cdot 3$ ゲルの構造回復性}

スメクトン SA の形成するゲルが，破壊後再び元の構造に回復 するまでの時間を $\omega=0.628 \mathrm{rad} / \mathrm{s} ， \gamma=0.8 \%$ における $G^{\prime}$ の時 間依存性から検討した。Fig. 6 にスメクトン SA 濃度を $1.5 \sim 3.0$ $\mathrm{wt} \%$ に变化させた際の $G^{\prime}$ の時間依存性を示す。その結果 $2.0 \mathrm{wt}$ \%では，非常に速い速度で弾性率が回復し，60sec 後にはほとん ぞ一定の $G^{\prime}$ を示した。また， $3.0 \mathrm{wt} \%$ では测定開始直後に弾性 率が回復しており, 濃度の上昇に伴い $G^{\prime}$ の值が一定に達する時 間が短縮し，ゲル形成速度が速くなっていることを認めた。また， $G^{\prime}$ の值が一定に達した後，緩やかではあるがわずかな $G^{\prime}$ の増大 が観察された。

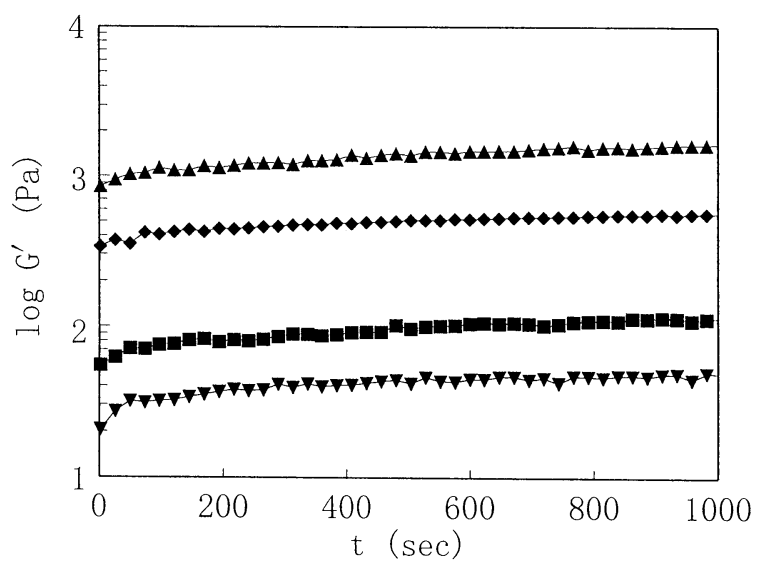

Fig. 6 Structural recovery of synthetic saponite/water dispersions at various concentrations. Solid concentration $($ wt $\%): \boldsymbol{\nabla}, 1.5 ; \mathbf{\square}, 2.0 ; \boldsymbol{\bullet}, 2.5 ; \boldsymbol{\Lambda}, 3.0$

\section{4. 結論}

スメクトン SA 水分散液の流動特性を測定し以下のような結果 を得た。

1）分散濃度 $1.1 \mathrm{wt} \%$ (体積分率 $0.44 \mathrm{vol} \%$ )以下で，分散液は ニュートニアン流動特性を，また $1.2 \mathrm{wt} \%$ (体積分率 $0.48 \mathrm{vol}$ \%)以上では, shear thinning 流動挙動を示しており，この 分散粒子濃度近傍で分散液内凝集構造が大きく変化する.

2）濃度 $1.5 \mathrm{wt} \%$ でスメクトン SA が形成するゲルは比較的高 い弾性率を示すが，小さい歪みで急激に構造が破壊される事 を認めた。

3）凝集エネルギーより求めたゲル構造の $G^{\prime}$ の指数は 5.3 で, $\mathrm{Na}$ 型ベントナイトや合成へクトライトよりも緩やかな凝集 状態を形成していることが推測される. 
4）ゲル構造の回復速度は非常に速く, $2.0 \mathrm{wt} \%$ では $60 \mathrm{sec}$ 後 には構造が回復した。

\section{参考文献}

1）福嶋喜章, スメクタイト研究会会報, 1, 16(1991).

2) van Olphen H, "An Introduction to Clay Colloid Chemistry” 2nd Ed., John Wiley Sons, New York(1977).

3）江頭和彦, “粘土ハンドブック第二版”, 日本粘土学会編 （1987），技報堂，p147.

4) 近藤三二, 粘土科学, 21, 1(1981).

5）鳥居一雄, 粘土科学, 25, 71(1985).

6）鈴木啓三, 前野昌弘, Fragrance J, 6, 29(1994).

7）和田光史, “粘土ハンドブック第二版”, 日本粘土学会編 （1987），技報堂，p108．
8) Newmann BS, Sanson KG, Clay Minerals, 8, 389(1970).

9）クニミネ工業(株)カタログ, スメクトンSA(1987).

10) Nakaishi K, Yasutomi R, Applied Clay Sci, 9, 71(1994).

11）中石克也, 農業土木学会論文集, 168, 117(1993).

12) Ramsay JDF, Daish SR, Wright GJ, Faraday Discuss Chem Soc, 65, 65(1978).

13) Sohm R, Tadros Th F, J Colloid Interface Sci, 132, 62(1989).

14) Buscall R, Mills PDA, Goodwin JW, Lawson DW, $J$ Chem Soc, Faraday Trans I, 84(12), 4249 (1988).

15) Miano F, Rabailo MR,Colloid Surfaces, 84, 229(1994).

16) Callaghan IC, Ottewill RH, Faraday Discuss Chem Soc, 57, 110 (1974).

17) Ramsay JDF, J Colloid Interface Sci, 109, 441(1986). 